\title{
Gebelikte Romatoid Artrit ve Yönetimi
}

\section{Rheumatoid Arthritis and Management in the Pregnancy}

\author{
Ayşe ÇİL AKINCI ${ }^{\mathrm{a}}$ (iD Fatma COŞAR ÇETIN $^{\mathrm{b}}$ iD
}

\begin{abstract}
ÖZET Romatoid artrit eklemleri ve birçok organı tutabilen sistemik, kronik ve otoimmün bir hastalıktır. Gebelikte romatoid artrit aktivitesinde azalma olmakta gebelik ilerledikçe iyileşme düzeyi artmaktadır. Romatoid artritli kadınlarda gebelik genellikle başarıyla sonlanmaktadır. Doğumdan sonraki ilk 3-12 ayda ise kadınlarda hastalık aktivitesi artmaktadır. Romatoid artritin gebelik öncesi yönetiminde hastalık sürecinin stabilize edilmesi, fetal riskleri azaltmak için ilaçların azaltılması ve teratojenik ilaçların kullanımından kaçınılması yer alır. Romatoid artritli kadın, antiromatizmal ilaçları alırken gebe kaldıysa fetal anomali taraması yapılır. Doğum sırasında eklem tutulumu nedeniyle gebeye pozisyon vermek güç olabileceğinden doğum şekline, multidisipliner bir değerlendirme sonrasında karar verilir. Doğum sonrası dönemde romatoid artrit aktivitesindeki artış nedeniyle gebelik öncesi dönemdeki ilaç tedavisi kullanılabilir. Bu nedenle anne sütüne geçen ilaçları kullanan kadınlar bebeklerini emzirmemelidir. Doğum sonrası dönemde eklem sorunları, deformiteleri, sınırlamaları ve hastalı̆ı̆ı neden olduğu ağrı nedeniyle bebek bakımı ve beslenmesi zor olabilir. Bu makalede; romatoid artritli kadınlarda gebelik öncesi, gebelik süreci ve doğum sonrası dönemdeki hastalık yönetimi ele alındı.
\end{abstract}

Anahtar Kelimeler: Doğum sonrası, gebelik, gebelik öncesi, romatoid artrit, tedavi

\begin{abstract}
Rheumatoid arthritis is a systemic, chronic, and autoimmune disease that can involve joints and many organs. There is a decrease in rheumatoid arthritis activity in pregnancy and the recovery level increases as pregnancy progresses. Among women with rheumatoid arthritis, pregnancy usually ends successfully. In the first 3-12 months after birth, the women's disease activity increases. Pre-pregnancy rheumatoid arthritis management includes stabilization of the disease process, reduction of drugs to reduce fetal risks, and avoiding the use of teratogenic drugs. If the woman with rheumatoid arthritis is pregnant while taking antirheumatic medicines, a fetal anomaly scan is done. The type of delivery is decided after a multidisciplinary evaluation because it may be difficult to give a position pregnant woman during labor due to joint involvement. Pre-pregnancy drug treatment can be used due to the increase in rheumatoid arthritis activity in the postpartum period. For this reason women used drugs passing into mother's milk should not breastfeed their babies. In the postpartum period, care and feeding of the baby can be difficult due to the joint problems, deformities, limitations and pain caused by the disease. In this review; disease management during preconceptional, perinatal and postnatal period were addressed in women with rheumatoid arthritis.
\end{abstract}

Keywords: Postnatal, perinatal, preconception, rheumatoid arthritis, treatment

\section{GíRiș}

Romatoid artrit (RA) özellikle eklemleri ve eklemlerin yanı sıra birçok organı da tutabilen sistemik, kronik ve otoimmün bir hastalıktır. ${ }^{1-3}$ Hastalık primer olarak bağ dokuda ve eklemlerde inflamasyona neden olur. Eklem inflamasyonu simetriktir ve multipl periferal eklem inflamasyonu şeklindedir. Hastalık sıklıkla alevlenmeler ve remisyon dönemleri ile seyreder. RA erken ve iyi tedavi edilmediğinde eklemlerde erozyon ve hasara, iş ve gelir kaybına ve kalıcı şekil bozukluklarına yol açar. ${ }^{1,2,4}$ RA dünya nüfusunun $\% 1$ 'ini etkilemektedir. Hastalık en s1k 30-50'li yaşlarda başlamakta olup kadınlarda erkeklere oranla üç kat daha fazla görülmektedir. ${ }^{1-6}$ RA'nın nedeni kesin olarak bilinmemektedir. Hastalığın etyolojisinde tek başına veya birlikte genetik faktörler, cinsiyet, sigara, bakteriler ve virüsler gibi etkenler yer almaktadır., ${ }^{1,7,8}$ RA'da başlangıçta spesifik olmayan ağrı, güçsüzlük, genel kırıklık, anoreksi ve kilo kaybı gibi inflamasyona ait klinik belirtiler görülür. ${ }^{1}$ Elin parmak eklemleri (\%35-40), el başparmak eklemi (\%25-30), el bileği (\%12-18), ayaklar, dirsek ve diz eklemleri en çok tutulan eklemlerdir. Etkilenen eklemde hareket ile artan ağrı, şişlik, hassasiyet oluşmakta ve sıklıkla bir saatten fazla süren sabah tutukluğu görülmektedir. ${ }^{9,10}$ Eklemlerdeki yakınmaların yanı sira RA'l1 hastaların \%50'sinde hastalık süresince herhangi bir zamanda eklem dışında

Geliş Tarihi/Received: 20-07-2017 / Kabul Tarihi/Accepted:23-09-2017

${ }^{a}$ Sorumlu yazar /Correspondence, Doç. Dr. İstanbul Medeniyet Üniversitesi, Sağlık Bilimleri Fakültesi Hemşirelik Bölümü,e-mail:aysecil2003@yahoo.co.ku, ORCID ID: 0000-0001-8270-0446

${ }^{b}$ Yard. Doç. İstanbul Medeniyet Üniversitesi, Sağlık Bilimleri Fakültesi Hemşirelik Bölümü, ORCID ID: 0000-0001-8755-488X 
sistemik bulgular da ortaya çıkmaktadır. ${ }^{8}$ Halsizlik, hafif ateş, kilo kaybı gibi sistemik belirtiler hastalığın ilk dönemlerinden itibaren ve bazen de eklem belirtilerinden daha ön planda olarak görülebilirler. RA eklem dişı diğer organ tutulumları da yapabilir. Bunlar; erken dönemde ağrısız, sert ve birkaç mm'den birkaç cm'ye kadar değişen boyutta ve sıklıkla alttaki periosta yapışık bazen hareketli derialtı nodülleri ve başta akciğer, larenks ve kalp olmak üzere birçok organda görülebilen visseral nodüllerdir. Hastalığın ilerlemesi ile kalp tutulumu, akciğer tutulumu, göz tutulumu, nörolojik tutulum, romatoid vaskülit gibi diğer organ hasarları gelişir. Bunların dışında; karaciğer, kas, böbrek tutulumu ve osteoporoz hem hastalığa hem de bu hastalığın tedavisinde kullanılan ilaçlara bağlı olarak görülebilmektedir. ${ }^{2}$ RA tanıs1 Amerikan Romatizma Derneği (American Rheumatism Association: ARA) tarafindan belirlenen kriterlere göre konmaktadır. Sabah katılığı, iki veya daha fazla eklem bölgesinde artrit, el eklemlerinin artriti, simetrik artrit, romatoid nodüller, romatoid faktör, radyografik değişiklikler değerlendirilerek tanı konulmaktadır. Sabah katılı̆̆ı, iki veya daha fazla eklem bölgesinde artrit, el eklemlerinin artriti, simetrik artrit bulgularının en az 6 haftadan beri devam etmesi tanı koymada yardımcidır., ${ }^{2,5,11}$ RA kronik bir hastalık olması nedeniyle küratif tedavisi bulunmamaktadır. Tedavinin amacı ağrıyı ve inflamasyonu azaltmak, eklem hasarını ve diğer komplikasyonları önlemek ve hastaların günlük aktivitelerini sürdürmesini sağlamaktır. ${ }^{1,2}$ RA tanısı alan hastalarda hastalığın şiddetine göre farmakolojik tedavi, fizik tedavi ve rehabilitasyon (soğuk uygulama, fizyoterapi, sabitleme, masaj ve elektroterapi), diğer önlemler (bandajlar, uğraş tedavisi, ortezler ve psikoterapi) ve cerrahi tedavi (sinovektomi, palyatif/rekonstrüktif cerrahi) uygulanabilmektedir. ${ }^{2}$ Hasta ve ailenin eğitilmesi, mümkün olduğunca bireysel bakımını ve alışılmış rollerini yerine getirmesi yönünde desteklenmesi, düzenli kontrollerin sağlanması ve multidisipliner bir ekip yaklaşımı tedavi başarısını olumlu yönde etkilemektedir. ${ }^{2,9,12,13}$ RA'da erken tanı ve uygun farmakolojik tedaviyle (özellikle ilk 2-3 ay içinde) kalıcı eklem hasarı engellenebilmektedir. RA tedavisinde nonsteroid anti inflamatuvar ilaçlar (NSAIII), kortikosteroidler ve hastalık seyrini değiştirici antiromatizmal ilaçlar (disease modifying anti rheumatic drugs: DMARD) kullanılmaktadır. ${ }^{2,9,12,14,15}$ NSAIİ; hastalığın seyrini değiştirmezler, inflamasyona neden olan prostaglandin sentezini önleyerek inflamasyon ve ağrıyı kontrol altına almak için kullanılırlar. ${ }_{1,2,13} \mathrm{Bu}$ ilaçların antiinflamatuvar özellikleri hastalık aktivitesini hafifletmede ve artralji, serözit ve ateş gibi spesifik semptomları direkt olarak düzeltmede yardımcıdır. $\mathrm{Bu}$ ilaçlar genellikle hastalar tarafindan iyi tolere edilirler, fakat uzun süreli maruziyet sonucu gastrit, peptik ülser, pıhtılaşma bozuklukları gibi yan etkiler oluşabilir. Altta yatan renal hastalığı olan hastalarda renal fonksiyonlar azalabilir ve hipertansiyon kötüleşebilir. ${ }^{16}$ Hastalığın tedavisinde kullanılan bir diğer farmakolojik ajan olan kortikosteroidler içinde en önemlisi kortizol (hidrokortizon)'dür. Düşük doz oral kortikosteroidler ağrnyı ve inflamasyonu azaltır ve kemik erozyonunun gelişimi ve ilerlemesini yavaşlatır. ${ }^{1,2,13}$ RA'da düşük doz kortikosteroid tedavisi sik kullanılmaktadır. Kortikosteroidler özelikle hastalık seyrini değiştirici antiromatizmal ilaçlarla birlikte kullanılmaktadırlar. Hastalık seyrini değiştiren ilaçların etkisi ortaya çıktıkça kortikosteroid dozu azaltılır. Kortikosteroidlerin sistemik kullanımlarından başka, eklemin içi kullanımları da vardır. ${ }^{2}$ Eklem içi kortikosteroid kullanımı geçici bir rahatlama sağlayabilir. ${ }^{1}$ DMARD; hastalığın seyrini değiştirerek hastalığı kontrol altına almak ve eklem yıkımını azaltmak amaciyla kullanılmaktadır. Bu ilaçlar aktif enfeksiyon döneminde kullanılmamalıdır. $\mathrm{Bu}$ gruba giren ilaçlar; antimalaryaller (klorokin ve hidroksi-klorokin), sulfasalazin, altın tuzları, D-penisil-amin, immünosüpresifler (metotreksat. Azatiyoprin, siklofosfamid, leflunomid, vs) ve biyolojik ajanlardır (tümör nekrozis faktör- $\alpha$ blokerleri, anakinra, abatasept, rituksimab). DMARD ilaçların bir kısmında etki yavaş başlar ve etkisi aylar sonra görülür. Ciddi yan etkileri olan bu grup ilaçlar kesilse bile etki ve yan etkileri uzun süre devam edebilir. Bu ilaçlardan immünosupresif olanların kemik iliği üzerine etkileri olduğundan bu ilaçları kullanan hastaların ayda bir kan sayımı yapılır ve hasta anemi, lökopeni ve trombositopeni yönünden izlenir., ${ }^{2,13,17}$

\section{Gebelikte Romatoid Artrit}

Doğurganlık döneminde RA insidans1 1/2.000'dir. ${ }^{6}$ RA'l1 hastaların \%75-80'inde gebelik döneminde hastalık aktivitesi ve farmakolojik tedavi ihtiyac1 azalmakta ${ }^{18,19}$ ve \% 50'den fazlasında birinci trimesterde düzelme olmaktadır. Gebelik haftası ilerledikçe hastalık 
Tablo 1. Gebelikte Amerikan Gida ve İlaç İdaresi (Food and Drug Administration: FDA) İlaç Emniyet Siniflandirmasi 26

\begin{tabular}{|c|c|}
\hline Kategori & Yorum \\
\hline \multirow[t]{2}{*}{$\mathrm{A}$} & Kontrollü çalışmalarda risk yok. \\
\hline & $\begin{array}{l}\text { Gebe kadınlarda yapılan yeterli ve iyi kontrollü çalışmalarda gebeliğin erken ve geç } \\
\text { dönemlerinde fetüs için herhangi bir risk oluşturmadığı gösterilmiștir. }\end{array}$ \\
\hline \multirow[t]{2}{*}{ B } & Kontrollü çalışmalarda insanda risk kanıtı yok. \\
\hline & $\begin{array}{l}\text { Hayvan çalışmalarında fetüs için herhangi bir risk oluşturmadığı gösterilmiştir, fakat } \\
\text { insanlarda yapılmış yeterli ve iyi kontrollü çalışmalar mevcut değildir. }\end{array}$ \\
\hline \multirow[t]{3}{*}{$\mathrm{C}$} & Risk göz ardı edilemez. \\
\hline & $\begin{array}{l}\text { Hayvan çalışmalarında fetüse zararlı olduğuna dair kanıtlar yok, fakat gebe kadınlarda } \\
\text { yapılmış yeterli ve iyi kontrollü çalışmalar yok. }\end{array}$ \\
\hline & $\begin{array}{l}\text { Veya hayvan çalışmalarında yan etki gösterilmiş, ancak gebe kadınlarda yapılmış } \\
\text { yeterli ve iyi kontrollü çalışmalar mevcut değildir. }\end{array}$ \\
\hline \multirow[t]{3}{*}{$\mathrm{D}$} & Risk için pozitif kanıt mevcut. \\
\hline & $\begin{array}{l}\text { Hayvan çalışmalarında yan etki gösterilmiştir, fakat gebe kadınlarda yapılmış yeterli ve } \\
\text { iyi kontrollü çalışmalar mevcut değildir. } \\
\text { veya }\end{array}$ \\
\hline & $\begin{array}{l}\text { Hayvan çalışmaları mevcut değildir ve gebe kadınlarda yapılmış yeterli ve iyi kontrollü } \\
\text { çalışmalar mevcut değildir. }\end{array}$ \\
\hline \multirow[t]{2}{*}{$\mathrm{X}$} & Gebelikte sakıncalı. \\
\hline & $\begin{array}{l}\text { Hayvan veya insan çalışmalarında fetal anormallikler gösterilmiştir veya insanlardaki } \\
\text { fetal risk potansiyel yararlı etkiden daha fazladır. }\end{array}$ \\
\hline
\end{tabular}

aktivitesi düzelmeye devam eder, en fazla düzelme genellikle ikinci veya üçüncü trimesterde görülür. Gebelik öncesi dönemde hastalık aktivitesi yüksek olan kadınlarda düzelmeler daha fazla olmaktadır., $4,18,19$ Gebelikte RA semptomlarındaki düzelmenin immünolojik değişikliklerden ve hormonal değişikliklerden kaynaklandığ 1 düşünülse de ${ }^{4,6}$ düzelmeye neden olan mekanizmalar henüz tam olarak aydınlatılamamıştır. ${ }^{4}$ Gebelikte belirtiler genel olarak düzelse bile, RA'nın klinik seyri gebelik öncesi dönemdeki gibi semptomlarda kısa süreli dalgalanmalarla karakterizedir. İlk gebeliğinde hastalık aktivitesinde iyileşme yaşayan çoğu kadın sonraki gebeliklerinde benzer bir iyileşme yaşamaktadır. RA'lı gebelerde genel olarak hastalık aktivitesinde azalma olsa da RA'lı gebelerin dörtte birinde gebelik süresince hastalık aktivitesinde herhangi bir iyileşme görülmemekte ve hatta az sayıda vakada hastalık kötüleşebilmektedir. ${ }^{4,6,19}$ RA'lı kadınlarda, gebelik genellikle başarıyla sonlanmaktadır. RA'lı kadınların gebelik-lerindeki düşük oranı normal kadınlardaki düşük oranı ile benzerdir. Spontan düşük, fetüs kaybı, preterm doğum, preeklampsi, fetal büyüme geriliği ya da perinatal mortalitede artış yoktur., ${ }^{4,6,16,18}$ RA'l1 gebelerde elektif sezaryen oranı sağlıklı kadınlara göre daha yüksektir. ${ }^{6}$ Hastaların çoğunda özellikle doğumdan sonraki ilk 3-12 ayda hastalık aktivitesi artmakta ve doğumdan sonraki ilk 6 ay içinde farmakolojik tedavi ihtiyacı artmaktadır. ${ }^{6,20}$ Hastalık aktivitesi, bu dönemde genellikle gebelik öncesindeki düzeye dönmekle birlikte daha kötü de olabilir.,20 Doğum sonrasında immün sistemi baskılayıc1 faktörlerin ortadan kalkması ve laktasyon sırasında artan prolaktin düzeyinin RA aktivitesinin artmasında etkili olduğu düşünülmektedir. ${ }^{6,18}$

\section{Gebelik Öncesi Dönemde İzlem}

Gebelikte fazla kilo alınması eklem yakınmalarını arttırabileceğinden gebelik planlayan RA'lı kadınların diyeti ve kilosu değerlendirilir, gebelik sırasında kilo kontrolünün sağlanmasına önem verilir. ${ }^{18}$ Eğer kadın obez ise obeziteyi azaltmak için girişimlerde bulunulur. Vitamin ve demir açısından zengin bir diyet verilir. Uzun süreli sulfasalazin kullanımı folik asit eksikliği ile sonuçlandığı için ilave folik asit kullanımı önerilir. Sigara kullanıyorsa sigarayı bırakması ve düzenli egzersiz yapması önerilir. ${ }^{13}$ Anemi öyküsü varsa, düzenli olarak hemoglobin düzeyi kontrol edilir ve gerekli ise demir, $B_{12}$ ve folat tabletleri ile tedavi edilir. Sabah katılığı ve eklemlerdeki hareket k1sıtlılığı nedeniyle özbakım yeteneği ve ileride bebeğin bakım ve beslenme gibi gereksinimlerini karşılama olasılığ1 değerlen-dirilir. Bebek bakımı ve beslenmesi sırasında karşılaşabileceği sorunları çözmek için doğum öncesi dönemde rehberlik alması, doğum sonrası dönemde ise yardım alması sağlanır. ${ }^{13}$ 
Tablo 2. Gebelik Sirasında Farmakolojik Tedavi 6,13,17,19,22,25,26

\begin{tabular}{|c|c|c|c|c|c|}
\hline \multicolumn{3}{|l|}{ İlaç } & İlaç Grubu & $\mathrm{KE}^{*}$ & Öneri \\
\hline \multirow[t]{6}{*}{ NSAİ̈ } & \multicolumn{2}{|l|}{ Parasetamol } & B & Yok & Hamilelik boyunca güvenlidir. \\
\hline & \multicolumn{2}{|l|}{ Aspirin } & $\mathrm{D}$ & Yok & $\begin{array}{l}\text { Gebeliğin ilk iki trimesteri boyunca, aspirin sadece açıça ihtiyaç } \\
\text { duyulduğunda ve fayda riski aştığında verilir. Üçüncü trimesterde tam } \\
\text { doz alındığında fetal ve maternal kanamaya neden olabileceğinden } \\
\text { kontraendikedir. }\end{array}$ \\
\hline & \multirow{2}{*}{\multicolumn{2}{|c|}{$\begin{array}{l}\text { Diğer NSAIII’lar } \\
\text {-İbuprofen (Brufen, Nurofen) } \\
\text {-Naproksen (Naprosin) }\end{array}$}} & $\mathrm{B} / \mathrm{D}$ & Yok & 1 ve 2 . trimesterde ciddi bir risk oluşturmamakta, fakat 3. trimesterde \\
\hline & & & & & $\begin{array}{l}\text { tehlike oluşturabilmektedir. Ozellikle indometazin ve ibuprofen } \\
\text { kullananlarda duktus arteriozusun erken kapanma riski vardır. }\end{array}$ \\
\hline & \multicolumn{2}{|c|}{-İndometazin (Indomed) } & & & \\
\hline & \multicolumn{2}{|c|}{$\begin{array}{l}\text {-Fenilasetik asit (Diklofenak) } \\
\text {-Ketoprofen (Ketocid) }\end{array}$} & & & \\
\hline Kortikosteroidler & \multicolumn{2}{|c|}{ Prednizolon (Deltakortril) } & $\mathrm{C}$ & Yok & İlk trimesterde $15 \mathrm{mg}$ 'dan düşük ya da eşit olacak şekilde kullanılır. \\
\hline \multirow[t]{10}{*}{ DMARD'lar } & $\begin{array}{l}\text { Antimalar- } \\
\text { yaller }\end{array}$ & $\begin{array}{l}\text { Klorokin (Aralen) / } \\
\text { Hidrosiklorokin } \\
\text { (Plaquenil) }\end{array}$ & $\mathrm{C}$ & Yok & Hamilelik boyunca güvenlidir. \\
\hline & Sulfasalazin & (Salazopirin) & $\mathrm{B}$ & Yok & Hamilelik boyunca güvenlidir. \\
\hline & \multirow{4}{*}{$\begin{array}{l}\text { İmmuno- } \\
\text { süpresifler }\end{array}$} & Azatiyoprin (Imuran) & $\mathrm{D}$ & Yok & Hamilelik boyunca güvenlidir. \\
\hline & & Metotreksat (Maxtrex) & $\mathrm{X}$ & Var & Gebelikten 3 ay önce ilaç kesilir. \\
\hline & & Leflunomid (Arava) & $\mathrm{X}$ & Var & Gebelik öncesi ilaç kesilir ve kandan ilaç temizlenir. \\
\hline & & Siklofosfamid & $\mathrm{D}$ & Var & Gebelikten 3 ay önce ilaç kesilir. \\
\hline & \multirow{4}{*}{$\begin{array}{l}\text { Biyolojik } \\
\text { ajanlar }\end{array}$} & TNF- $\alpha$ blokerleri & $\mathrm{B}$ & Yok & Kaçırılan dönemde ya da pozitif gebelik testinden sonra ilaç bırakılır. \\
\hline & & Etanercept (Enbrel) & & & \\
\hline & & Abatacept & $\mathrm{C}$ & Var & Gebelikten 3 ay önce ilaç kesilir. \\
\hline & & Rituximab & $\mathrm{C}$ & Var & Gebelikten 6-12 ay önce ilaç kesilir. \\
\hline
\end{tabular}

*KE: Kontraendikasyon 
RA'yı kontrol altına almak amaciyla kullanılan farmakolojik ajanların anne ve fetüs üzerine olumsuz etkileri olabileceğinden gebelik süresince hatta gebelik öncesi dönemde bu ajanların hem anne hem de fetüs üzerindeki olumsuz etkilerini önlemeye yönelik önlemlerin alınması gerekir. ${ }^{16}$ RA'nın gebelik öncesi yönetimi altta yatan hastalı sürecinin stabilize edilmesini, erken fetal riskleri en aza indirgemek için kullanılan ilaçların azaltılmasını ve bilinen teratojenik ajanların kullanımından kaçınılmasını kapsar. ${ }^{4}$ Gebelik planlanırken hastalık aktivitesini değerlendirmek ve ilaç tedavisinde düzenlemeler yapmak için romatolog ile görüşülür. Gebelik öncesi, gebelik ve doğum sonrası dönemde farmakolojik ajanların kullanımında Amerikan Gıda ve İlaç İdaresi (Food and Drug Administration: FDA) tarafindan yapılan ilaç emniyet sınıflandırması dikkate alınır (Tablo 1). DMARD ilaçlar; NSAIII'ler veya steroidler gibi diğer ilaçlarla değiştirilebilir. ${ }^{13}$ Gebe kalmada sorun yaşandığında, hastaların NSAIII kullanımını bırakmaları veya dikkatli kullanmaları önerilmektedir. ${ }^{21} \mathrm{Bu}$ hastalara analjezik olarak parasetamol verilir (Tablo 2). NSAIII ilaçlar arasında yer alan aspirin artralji ve ateşi tedavi etmede çok etkilidir. Kronik aspirin kullanımı gebeliği ve doğumu uzatabilir ve doğumda maternal kanama riskini arttırabilir. Fetüste ve yenidoğanda kanama, duktus arteriyozusun erken kapanması da aspirin kullanımı ile ilgili bir sorundur. Doğumdan önceki son haftada 5-10 mg aspirin kullanılmas1 anormal trombosit agregasyonuna neden olur annede kan kaybını arttırır, bunun yanında yenidoğanda da kanama komplikasyonlarına ve anormal trombosit agregasyonuna neden olur. ${ }^{16}$ Bu olumsuz etkileri nedeniyle NSAIII'lerin birinci ve ikinci trimesterde az miktarda kullanılması ve gebeliğin üçüncü trimesterinde kullanımının tamamiyla durdurulması öneril-mektedir (Tablo 2). ${ }^{21}$ Diğer NSAIII'ler de RA'nın semptomlarını kontrol etmede oldukça etkilidir, fakat bu ilaçların güvenlikleri ile ilgili endişeler de vardır. Üçüncü trimesterde NSAIII'ler fetal veya obstetrik komplikasyonlara neden olur. İndometazin doğumu baskılar, fetal üriner atımı azaltır. İlave olarak uzun süre indometazin kullanımı duktus arteriyozusun erken kapanmasina neden olur. Bununla birlikte bu bulgu ilacin kesilmesi ile birlikte düzelmektedir. Kısa süreli kullanımları bazı klinik durumlarda yararlı olabilse de uzun süre kullanım için fetüste duktus arteriyozusun ve amniotik sivi volümünün değerlendirilmesi uygun olur. Aspirin ile birlikte NSAIII'nin gebeliğin erken döneminde kullanılmasının teratojenite riskini arttırdığına yönelik bulgu yoktur (Tablo 2). ${ }^{13,16}$

Prednizon gibi kortikosteroidler RA tedavisinin önemli bir parçasıdır. Anneyi tedavi ederken çok az miktarda aktif ilaç fetal dolaşıma geçeceğinden prednizon en ideal kortikosteroiddir. ${ }^{21}$ Kortikosteroidlere maruz kalan fetüs büyümede gecikme açısından yüksek risklidir, fakat bu durum ilacin etkisinden ziyade annenin altta yatan tıbbi durumu nedeniyle olabilir. Sonuç olarak prednizonun fetüs üzerine bilinen bir riskinin olmadığ düşünülmekte ve bu nedenle gebelik sirasinda RA tedavisinde kullanılmaktadır (Tablo 2) ${ }^{16}$ Kortikosteroid maruziyetinin fetal riskleri anlamlı olmamasına rağmen maternal riskleri açıkça vardır ve bu riskler doz ile ilişkilidir. Bildirilen riskler arasında glikoz intolerans1, infeksiyona eğilim, katarakt, osteopeni, hipertansiyon, femoral kemik başında avasküler nekroz yer alır. $\mathrm{Bu}$ nedenle RA alevlenmelerinde hastayı etkili en düşük doz ile tedavi etme yoluna gidilmelidir. ${ }^{16,21}$ Yine gebelik sırasında ortaya çıkabilen osteopeni gibi sorunlar kortikosteroidlerle daha da kötüleşebilir; bu nedenle uygun izlem ve kalsiyum ve D vitamini

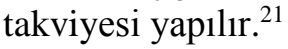

DMARD'lar arasinda yer alan antimalaryallerin gebelik sirasinda kullanılması tartışmalıdır. Bununla birlikte gebelik sırasında hastalığı kontrol etmek için gereksinim duyulan en düşük dozda antimalaryal tedaviye devam etmek bazı klinik durumlarda uygun olabilir. ${ }^{16}$ Klorokin (Aralen) ve hidroksiklorin (Plaguenil) romatoid artrit tedavisinde kullanilan antimalaryal ilaçlardır. Hidroksiklorin daha az toksiktir ve klinik pratikte klorokinden daha yaygın olarak kullanılmaktadır. Günlük olarak 200-400 mg dozunda hidroksiklorin kullanımının konjenital anomali veya düşük riskinde artışa neden olmadığ ${ }_{1}$ bildirilmekte, ${ }^{16,19,21}$ hidroksiklorin kullanan gebelerde retinal toksisiteyi değerlendirmek için 6-12 ayda bir göz muayenesinin yapılması önerilmektedir. ${ }^{16} \mathrm{~K}$ saca belirtmek gerekirse gebelik öncesi, gebelik sirasında ve emzirme döneminde hidroksiklorin kullanımı güvenlidir (Tablo 2). ${ }^{21}$ DMARD arasında yer alan sulfasalazin kullanan hastalarda folat eksikliği görülebilir, bu nedenle gebe kadınlarda sulfasalazin kullanımı sırasında en az $800 \mu \mathrm{g}$ folik asit replasmanına devam edilmesi ve bazen arttırılması gerekebilir. ${ }^{21}$

Gebelik sirasında kullanılmasına izin verilen tek immünosüpresif ajan azatiyoprin (Imuran)'dır (Tablo 2). Romatolojik hastalığ 
olanlarda yaygin olarak kullanılan metotreksat ve siklofosfamidin hayatı tehdit eden bir hastalık olmadıkça ve diğer önlemler yetersiz kalmadıkça gebelikte kullanılması öneril-mez. ${ }^{16,19}$ İlaç toksisitesi açısından izlem; her 1-3 ayda bir tam kan sayım1, trombosit sayımı ve karaciğer fonksiyon testlerinin bakılmasını kapsar. Azatiyoprine uterusta maruz kalan bazı infantlarda doğumda lökopeni ve trombositopeni görüldügünden üçüncü trimesterde aylık izlem yapılması önerilmektedir. Maternal lökosit sayısı anlamlı derecede normalin altına düşerse azatiyoprin dozu yarıda birakılır. Fetal karaciğerde azatiyoprini aktif metabolitlerine çeviren enzim eksik olduğundan gebeliğin erken dönemlerinde fetüs azatiyoprinin etkilerinden korunmalıdır. Azatiyoprin ile tedavi edilen gebelerde metarnal hastalığın ve uygun fetal büyümenin izlenmesi gerekir. Sonuç olarak gebelik sirasında azatiyoprin kullanımının yararları risklerinden fazla olduğu için bu ajan dikkatli bir şekilde kullanılmalıdır. ${ }^{16}$ Gebelikte metotreksat kullanımı fetal anomali riski oluşturmaktadır. Çocuk doğurma potansiyeline sahip tüm kadınlara, metotreksat alırken güvenilir biçimde kontrasepsiyon kullanmaları önerilir. Yakın gelecekte gebelik planlanması veya hekim hastanın kontrasepsiyon yöntemlerinin güvenilir olmadığını düşün-düğünde alternatif ajanların kullanımı düşünülür. Aynı kısıtlamalar erkek hastalar için de geçerlidir. Metotreksat kullanan bir kadın gebe kalırsa, metotreksatı bırakmalı, konjenital anomali riski yönünden değerlendirme yapılmalıdır. ${ }^{19,21}$ Metotreksat tedavisi gören bir kadın gebelik planlarsa, ilacın elimine edilmesi için gebe kalmadan en az 3 ay önce metotreksatı bırakmas1 önerilmektedir. ${ }^{19,21}$ Leflunomidin hayvanlarda başta merkezi sinir sistemi ve iskelet anomalileri olmak üzere fetal anomallilere neden olduğu bilinmektedir. Leflunomid gebelikten iki yıl öncesine veya plazmaya leflunomid düzeyleri $0.02 \mathrm{mg} / \mathrm{L}$ 'in altına düşünceye kadar kesilir. Eğer leflunomid ile tedavi edilen bir kadın gebe kalmak istiyorsa, ilaç durdurulur ve kan seviyelerini bu seviyeye düşürmek için kolestiramin verilir. $\mathrm{Bu}$ arada kontraseptif önlemler alınır. ${ }^{19,21}$ Gebelik öncesi hastalık aktivitesi değerlendirildikten sonra immünosüpresif ilaçlardan siklofosfamid gebelikten üç ay önce kesilir. ${ }^{18}$ Siklofosfamid gebeliğin ilk yarısında kontrendike olup, gebeliğin ikinci yarısında hastalık aktivitesi fazla olan kadınlarda dikkatle kullanılır. ${ }^{21}$ Gebelik öncesi ve gebeliğin erken dönemlerinde gelişen fetüsün biyolojik ajanlar içerisinde yer alan TNF- $\alpha$ blokerlerine maruziyetten olumsuz bir şekilde etkilenmediği ve gebeliğin ilerleyen aşamalarında hastalık aktivitesi yüksek olan kadınlarda devam eden TNF inhibisyonunun potansiyel yararlarının zararlarına ağır basabileceği bildirilmektedir. ${ }^{22}$ $\mathrm{Bu}$ ilaçların fetüs üzerindeki etkileri tam olarak bilinmemektedir. İlave olarak bu ilaçlar protein yapisindadır, gastrointestinal sisteminde sindirilirler ve sistemik dolaşıma absorbe edilmezler. Yine de dikkatli kullanılmaları sağlanmalı ve uygun kullanım konusunda kadınlara danışmanlık verilmelidir. ${ }^{21}$ RA' 11 kadın, biyolojik ajanları kullanırken gebe kalırsa konjentital anomali açısından prenatal değerlendirme yapılmalıdır. ${ }^{13}$

\section{Gebelik Döneminde Tedavi ve İzlem}

RA'lı hastalarda obstetrik izleme yönelik özel bir kılavuz bulunmamaktadır. Preterm doğum, preeklampsi veya fetal büyüme geriliği yönünden belirgin olarak artmış bir risk olmadığından, normal obstetrik bakım için yapılan obstetrik izleme devam edilir. ${ }^{23}$ Gebe RA ile ilgili sorun yaşıyorsa romatolog tarafından gebelik boyunca 2-4 haftada bir değerlendirilir. Dinlenme RA'nın yönetimde önemlidir, bu nedenle RA'lı gebenin yeterli düzeyde dinlenmesi sağlanır. Fizik tedavi, hastalığı gebelik sirasında düzelmeyen RA'l1 gebelerde yararlı olabilir. Basit analjezi için parasetamol kullanılması önerilir. Mümkünse NSAIII'lerden ve aspirin kullanımından kaçınılır. NSAIİ gerekli olduğunda inflamasyonu kontrol altına almak için gereken minimum dozda kullanılır. Gebelik sırasında hastalık aktivitesinde iyileşme olmayan hastalarda kortikosteroidler kullanılabilir. Gebelik süre-since düşük dozlarda prednizon RA'y1 kontrol altında tutmak için genellikle yeterli olur. Gebelikte gerekliyse intraartiküler steroidler de kullanılabilir. Obstetrik bakım sağlayan hekim özellikle hastanın DMARD veya steroid kullanması durumunda romatolog ile işbirliği içinde çalışır. Hidroksiklorokin kullanan gebelerin ilaç toksisitesi yönünden değerlen-dirilmesi için bir oftalmolog tarafindan göz muayenesinin yapılması gerekebilir. Metotreksat ilk trimesterde kesinlikle kontrendikedir ve bundan sonra da nispeten kontraendikedir. Leflunomid (Arava), gebe kadınlarda değil aynı zamanda gebelik planlayan üreme çă̆ında kadınlarda da kontrendikedir. Anti-TNF ilaçların gebelikte güvenliği bilinmemektedir ve bu nedenle kullanımından kaçınılır (Tablo 2). 4,22,23 


\section{Doğum Sürecinde Tedavi ve İzlem}

RA gebelik sonuçlarında hiç ya da çok az olumsuz etkiye sahiptir. Nadir olarak, ağır deforme RA vajinal doğum mekaniği için bir sorun teşkil edebilir; bu tür durumlar önceden belli olduğundan gerekli planlamalar yapilır. ${ }^{4}$ Doğum sirasında eklem tutulumuna göre gebeye pozisyon verilmesinde güçlükle karşılaşılabilir. Kalçaların abdüksiyonuyla ilgili problemler, özellikle litotomi pozisyonunun sağlanmasında sorun oluşturabilir. Doğum şekli, gebenin takibinde multidisipliner bir değerlendirme sonrası kararlaştırılır. Sezeryan doğumun RA'l1 gebelerde yaygın olarak kullanıldığı bildirilmekle birlikte hastalık aktivitesi düşük olan gebelere göre hastalık aktivitesi orta-yüksek olan gebelerde sezeryan doğum oranlarının daha fazla olduğu da bildirilmektedir. ${ }^{24}$ Bir önceki y1lda kronik kortikosteroid tedavisi gören tüm hastalara sezeryan doğum sırasında ya da doğum sirasında stres dozu kortikosteroid verilir. Bu uygulama bu hastalarda beklenen endojen adrenal yetmezliği ortadan kaldırır. ${ }^{4,25}$

\section{Doğum Sonrası Dönemde Tedavi ve İzlem}

RA'lı kadınların yaklaşık \% 90'1 doğumdan sonraki ilk 3 ay içinde RA atağ geçirir, bu risk ilk gebelikten sonra biraz daha yüksektir. RA'l1 kadınların çoğunda postpartum dönemde belirtiler akut ve şiddetli bir şekilde başlayabileceğinden RA'lı kadınlarda doğum sonrası dönemde eklemlerdeki ağrı nedeniyle depresyon görülebilir. İlave olarak postpartum dönemde belirtiler akut ve şiddetli bir şekilde başlayabileceğinden gebelik öncesi ilaç tedavisine dönülebilir. Annelerin ilaçların anne sütüne geçişi ile ilgili olarak bilgilendirilmeleri, anne sütüne geçen ilaçları kullanan annelerin bebeklerini emzirmemesi sağlanır. Amerikan Peditari Akademisi (Amerikan Academy of Pediatrics: AAP) tarafindan emzirmeye uyumlu olduğu düşünülen NSAİ̈'ler; ibuprofen, indometazin, diklofenak, naproksen, piroksikam, ketorolak ve tolmetin'dir. İbuprofen, anne sütünde düşük bir seviyededir ve kısa yarılanma ömrüne sahiptir ve bu nedenle laktasyondaki anne için analjezik olarak uygun bir seçenektir. Küçük-orta dozlarda kortikosteroid kullanan kadınlarda sütte ölçülen ilaç düzeyi anne tarafindan alınan toplam prednizolon dozunun tipik olarak \% 0.1 'inden azdır ve bebeğin endojen kortizol üretiminin \%10'undan azdır. Bu dozdaki kortikosteroidlerin gelişmekte olan bebeğe olumsuz etkileri bulunmamaktadır. Hidroksiklorin anne sütüne geçme oranı çok düşüktür ve bu düzeyin toksik olduğu düşünülmemektedir. Sulfasalazin kullanan annelerin bebeklerinde yenidoğan sarıllğı görülebilir. $\mathrm{Bu}$ nedenle preterm doğan veya sarıllı̆g1 olan bebeklerin annelerinin laktasyon sirasında sulfasalazin kullanımını 1-2 ay bırakmas1 gerekebilir. Prematürite, hiperbilirubinemi veya diğer akut stresler dişında sulfasalazin laktasyon sırasında güvenli kabul edilir. Azatiyoprinin, emzirme döneminde bebeğe yüksek bir risk oluşturmadan alınabileceği düşünülmektedir. Siklofosfamid kullanımı sırasında laktasyon kontrendikedir. Metotreksat ve leflunomid maruziyetinin bebeği nasıl etkileyebileceği bilinmemektedir ve bu nedenle metotreksatın ve leflunomidin daha fazla veri elde edilinceye kadar emzirme sirasında kullanımının güvensiz olduğu düşünülmektedir. ${ }^{21}$ Yine hastalık nedeniyle ortaya çıkan eklem problemleri, şekil bozuklukları, kısıtl111klar, ağrı bebeği tutma ve besleme gibi maternal başa çıkma becerilerini engelleyebilir. $\mathrm{Bu}$ konuda anneye yardım sağlanır. Hareketi yetersiz olan annelerin doğum sonrası venöz tromboemboli riski altında olması nedeniyle koruyucu önlemler alınır., ${ }^{413}$

\section{Sonuç}

RA'l1 gebelerde hastalık aktivitesinde azalma olmakta gebelik haftası ilerledikçe hastalık aktivitesindeki azalma miktarı artmakta ve gebelikler genellikle başarıla sonlanmaktadır. Bununla birlikte doğumdan sonraki ilk 3-12 ayda kadınlarda hastalık aktivitesi artmaktadır. RA'nın gebelik öncesi yönetimi hastalı aktivitesinin kontrol altına alınması, fetal riskleri azaltmak için kullanılan tedavi protokollerinin yeniden düzenlenmesi ve teratojenik ilaçların kullanımından kaçınılması gerekir. Bazı ilaçların (metotreksat ve siklofosfamid gibi) gebelikten 3 ay önce kullanımının bırakılması gerekir. Yine leflunomid gebelikten iki yıl öncesine veya plazmaya leflunomid düzeyleri $0.02 \mathrm{mg} /$ L'in altına düşünceye kadar kesilir. RA'lı kadın, metotreksat, siklofosfamid ve leflunomid gibi DMARD ilaçları alırken hamile kalırsa derhal tıbbi tedavi bırakılır, konjenital anomali yönünden tarama yapılır. NSAIII'ler birinci ve ikinci trimesterde düşük düzeyde kullanılabilir, gebeliğin üçüncü trimesterinde tamamıyla durdurulur. Kortikosterod kullanımına gebelik süresince devam edilir. DMARD ilaçlardan antimalaryaller, sulfasalazin ve azatiyoprin gebelik sırasında kullanılabilir. Doğum sırasında eklem tutulumu nedeniyle gebeye pozisyon 
vermek güç olabilir. Doğum şekline, multidisipliner bir değerlendirme sonrasında karar verilir. Doğum sonrası dönemde hastalık aktivitesinde artış olabileceğinden gebelik öncesi dönemdeki ilaç tedavisine dönülebilir. Anne sütüne geçen ilaçları kullanan annelerin bebeklerini emzirmemesi sağlanır.

\section{Kaynaklar}

1. Güneş Z. İmmun sistem hastalıkları. İçinde: Çelik S, Yeşilbalkan ÖU, çeviri editörleri. Dahili ve Cerrahi Hastalıklar Hemşireliği. Ankara: Nobel Akademik Yayıncılık Eğitim ve Danışmanlık; 2015. ss 348379.

2. Memiş S. Romatizmal hastalıklar. İçinde: Karadakovan A, Eti Aslan F, editörler. Dahili ve Cerrahi Hastalıklarda Bakım, İstanbul: Nobel Kitabevi; 2010. ss 1357-1379.

3. Rupp I, Boshuizen HC, Jacobi CE, Dinant HJ, van den Bos GA. Impact of fatigue on health-related quality of life in rheumatoid arthritis. Arthritis Care \& Research 2004; 51(4):578-585.

4. Denney JM, Porter TF, Branch DW. Autoimmune diseases. In: James D, Steer PJ, Weiner CP, Gonik B, Crowther CA,. Robson SC, eds. High Risk Pregnancy Management Options. China: Saunders; 2011. pp 763-794.

5. Kınıklı G. Romatoid Artrit. İçinde: Düzgün N, editör. Romotoloji, Pfizer İnflamasyon; 2011. ss 124-140. Avaible: http://ichastaliklariromatoloji.medicine.ankara.edu.t r/files/2014/02/Romatoid-Artrit.pdf via the INTERNET. Accessed 2017 March 11.

6. A Gcelu. Rheumatic diseases and pregnancy. South African Medical Journal 2014; 104(9): 643.

7. Nikolaus S, Bode C, Taal E, de Laar MA. Fatigue and factors related to fatigue in rheumatoid arthritis: a systematic review. Arthritis Care \& Research 2013; 65(7): 1128-1146.

8. Özsoy MH, Altınel L, Başarır K, Çavuşoğlu AT, Dinçel VE. Romatoid artritte eklem hastalığının patogenezi. TOTBID Dergisi 2006; 3: 101-110.

9. Behzad Heidari, Rheumatoid Arthritis: Early diagnosis and treatment outcomes. Caspian Journal of Internal Medicine 2011; 2(1): 161-170.

10. Hewlett S, Carr M, Ryan S, Kirwan J, Richards P, Carr A, Hughes R. Outcomes generated by patients with rheumatoid arthritis: how important are they? Musculoskeletal Care 2005; 3(3): 131-142.

11. MacGregor JA, Silman JA. Classification and epidemiology. In: Rheumatology. Ed's; Hochberg CM, Silman JA, Weinblatt EM, Weisman HM, Smolen SJ. Mosby, Fourth Edition, 2008, pp;755761.

12. Cornell P. Management of patients with rheumatoid arthritis. Nursing Standard 2007; 22(4): 51-57.

13. Pincus T, Yazici Y, Sokka T, Aletaha D, Smolen J. Methotrexate as the "anchor drug" for the treatment of early rheumatoid arthritis. Clinical and Experimental Rheumatology 2003; 21: S179-85.

14. Robson SE, Hodgett S. Autoimmun disorders. In: Robson SE, Waugh J, eds. Medical Disorders in Pregnancy: A Manual for Midwives. Singapore: Blackwell Publishing Ltd; 2008. pp 137-146.

15. Yıldırım R, Yazıcı Y. Romatoid artritte erken tedavi. RAED Dergisi 2012; 4(2): 59-67.

16. Peaceman A, Ramsey-Goldman R. Autoimmune Connective Tissue Disease in Pregnancy. The Global Library for Women's Medicine 2008. Avaible:

https://www.glowm.com/section_view/heading/Aut oimmune\%20Connective\%20Tissue\%20Disease $\% 2$ 0in\%20Pregnancy/item/167 via the INTERNET. Accessed 2017 March 11.

17. Demirel A, Kırnap M. Romatoid artrit tedavisinde geleneksel ve güncel yaklaşımlar. Sağlık Bilimleri Dergisi 2010; 19(1) 74-84.

18. Çalgüneri M, Akdoğan A. Gebelik ve romotolojik hastalıklar. İçinde: Ayhan A, Durukan T, Günalp S, Gürcan T, Önderoğlu LS, Yaralı H, Yüce K, editörler. Temel Kadın Hastalıkları ve Doğum Bilgisi 1. Cilt. 2. Baskı. Anakara: Güneş Tıp Kitabevi; 2008. ss 321-331.

19. Mitchell K, Kaul M, Clowse MEB. The management of rheumatic diseases in pregnancy. Scandinavian Journal of Rheumatology 2010; 39(2): 99-108.

20. Jain V, Gordon C. Managing pregnancy in inflammatory rheumatological diseases. Arthritis Research \& Therapy 2011; 13: 206.

21. Elliott $\mathrm{AB}$, Chakravarty EF. Immunosuppressive medications during pregnancy and lactation in women with autoimmune diseases. Women's Health (2010); 6(3): 431-442.

22. Temprano KK, Florea SC, Salt E. Rheumatoid Arthritis and Pregnancy. Medscape. Jul 24, 2015. Avaible:

http://emedicine.medscape.com/article/335186overview\#a1 via the INTERNET. Accessed 2017 July 11.

23. Gomes V, Mesquita A, Capela C. Autoimmune diseases and pregnancy: Analysis of a series of cases. BMC Research Notes 2015; 8(1): 216 .

24. Gerosa M, Schioppo T, Meroni PL. Challenges and treatment options for rheumatoid arthritis during pregnancy. Expert Opin Pharmacother 2016; 17(11): $1539-47$.

25. Bozkurt M, Uçar D. Gebelikte Romatoid Artrit Tedavisi: Derleme. Konuralp Tip Dergisi 2013; 5(2): 62-69

26. de Man YA, Hazes JM, van der Heide H, et al. Association of higher rheumatoid arthritis disease activity during pregnancy with lower birth weight: results of a national prospective study. Arthritis Rheum. 2009; 60(11): 3196-3206 